\title{
Article \\ p-CuO/n-ZnO Heterojunction Structure for the Selective Detection of Hydrogen Sulphide and Sulphur Dioxide Gases: A Theoretical Approach
}

\author{
Hasan Albargi 1,2(D), Hussein Y. Ammar 2,3,*(D), Heba M. Badran 2,3, Hassan Algadi 1,4 (D) and Ahmad Umar 1,5,*(D) \\ 1 Promising Centre for Sensors and Electronic Devices (PCSED), Najran University, Najran 11001, Saudi Arabia; \\ albargih@yahoo.com (H.A.); hassan.algadi@gmail.com (H.A.) \\ 2 Department of Physics, Faculty of Science and Arts, Najran University, Najran 11001, Saudi Arabia; \\ drhebabadran@gmail.com \\ 3 Physics Department, Faculty of Education, Ain Shams University, Cairo 11566, Egypt \\ 4 Department of Electrical Engineering, Najran University, Najran 11001, Saudi Arabia \\ 5 Department of Chemistry, Faculty of Science and Arts, Najran University, Najran 11001, Saudi Arabia \\ * Correspondence: hyammar@hotmail.com (H.Y.A.); ahmadumar786@gmail.com (A.U.)
}

\section{check for}

updates

Citation: Albargi, H.; Ammar, H.Y.; Badran, H.M.; Algadi, H.; Umar, A. p-CuO/n-ZnO Heterojunction Structure for the Selective Detection of Hydrogen Sulphide and Sulphur Dioxide Gases: A Theoretical Approach. Coatings 2021, 11, 1200. https://doi.org/10.3390/ coatings 11101200

Academic Editors: Anna Sandak and Keith J. Stine

Received: 30 August 2021

Accepted: 27 September 2021

Published: 30 September 2021

Publisher's Note: MDPI stays neutral with regard to jurisdictional claims in published maps and institutional affiliations.

Copyright: (c) 2021 by the authors. Licensee MDPI, Basel, Switzerland. This article is an open access article distributed under the terms and conditions of the Creative Commons Attribution (CC BY) license (https:/ / creativecommons.org/licenses/by/ $4.0 /)$.

\begin{abstract}
DFT calculations at the B3LYP/LanL2DZ level of theory were utilized to investigate the adsorption of $\mathrm{H}_{2} \mathrm{~S}$ and $\mathrm{SO}_{2}$ gases on the electronic properties of $\mathrm{CuO}-\mathrm{ZnO}$ heterojunction structures. The results were demonstrated from the standpoint of adsorption energies ( $E_{\text {ads }}$ ), the density of states (DOS), and NBO atomic charges. The obtained values of the adsorption energies indicated the chemisorption of the investigated gases on $\mathrm{CuO}-\mathrm{ZnO}$ heterojunction. The adsorption of $\mathrm{H}_{2} \mathrm{~S}$ and $\mathrm{SO}_{2}$ gases reduced the HOMO-LUMO gap in the $\mathrm{Cu}_{2} \mathrm{Zn}_{10} \mathrm{O}_{12}$ cluster by $4.98 \%$ and $43.02 \%$, respectively. This reveals that the $\mathrm{Cu}_{2} \mathrm{Zn}_{10} \mathrm{O}_{12}$ cluster is more sensitive to the $\mathrm{H}_{2} \mathrm{~S}$ gas than the $\mathrm{SO}_{2}$ gas. The $\mathrm{E}_{\mathrm{ads}}$ values for $\mathrm{SO}_{2}$ and $\mathrm{H}_{2} \mathrm{~S}$ were -2.64 and $-1.58 \mathrm{eV}$, respectively. Therefore, the $\mathrm{Cu}_{2} \mathrm{Zn}_{10} \mathrm{O}_{12}$ cluster exhibits a higher and faster response-recovery time to $\mathrm{H}_{2} \mathrm{~S}$ than $\mathrm{SO}_{2}$. Accordingly, our results revealed that $\mathrm{CuO}-\mathrm{ZnO}$ heterojunction structures are promising candidates for $\mathrm{H}_{2} \mathrm{~S}$ - and $\mathrm{SO}_{2}$-sensing applications.
\end{abstract}

Keywords: $\mathrm{CuO} / \mathrm{ZnO}$ heterostructure; gas sensors; $\mathrm{H}_{2} \mathrm{~S}$ gas; $\mathrm{SO}_{2}$ gas; DFT

\section{Introduction}

Environmental pollution has recently reached an alarming level as a result of fast industrialization, which has resulted in an increase in the number of poisonous and dangerous gases and chemicals in the atmosphere [1-4]. Because of their colorless and odorless nature, most gases are breathed by humans without their knowledge, causing serious health problems and even death [5-8]. As a result, developing sensors and systems that can effectively identify such dangerous and hazardous pollutant gases is critical [9-13]. Solid electrolyte gas sensors, electrochemical gas sensors, metal oxide semiconductor sensors (MOS), catalytic combustion gas sensors, and other types of gas sensors have been documented in the literature [14-17]. MOS type sensors are among the most researched of the many types of gas sensors because they may be used to detect a variety of gases at lower concentrations merely by studying the change in resistance induced by the interaction between the sensing material and the target gas [18-21]. The operating concept of a gas sensor is based on changes in the sensing material's electrical conductivity. Most target gas molecules are adsorbed by oxygen ions that have already been adsorbed at the metal-oxide surface due to the large number of surface sites. The charge carrier concentration can be modulated via interactions between adsorbed target species and oxygen ions, changing the material's conductivity (or resistivity) [20].

Hydrogen sulphide $\left(\mathrm{H}_{2} \mathrm{~S}\right)$ and sulphur dioxide $\left(\mathrm{SO}_{2}\right)$ are extremely toxic, colorless, poisonous, and dangerous gases that do not only pollute the environment but also represent 
a major health risk to humans [22-25]. Inhaling such gases can cause serious health issues in humans, such as eye inflammation, respiratory tract infections, asthma, cardiac damage, cancer, and irreversible pulmonary impairment, and so on [26-30]. As a result, an efficient technique for detecting such hazardous gases is necessary.

Metal oxide semiconductor (MOS)-based resistive sensors have recently attracted a lot of interest because of their ease of manufacture and inexpensive cost, as well as their quick, programmable, sensitive, and selective response [27-33]. The performance of MOS-based sensors can be improved by using semiconductor metal oxide nanomaterials as sensing material because the nanomaterials have a higher specific surface area, which increases the interaction between the sensing material and the target gas and, thus, improves the sensing response $[1,2,4,5]$. Metal oxide nanomaterials such as zinc oxide $(\mathrm{ZnO})$, copper oxide $(\mathrm{CuO})$, tin oxide $\left(\mathrm{SnO}_{2}\right)$, tungsten oxide $\left(\mathrm{WO}_{3}\right)$, nickel oxide $(\mathrm{NiO})$, cobalt oxide $\left(\mathrm{Co}_{3} \mathrm{O}_{4}\right)$, iron oxide $\left(\mathrm{Fe}_{2} \mathrm{O}_{3}\right)$, titanium oxide $\left(\mathrm{TiO}_{2}\right)$, indium oxide $\left(\mathrm{In}_{2} \mathrm{O}_{3}\right)$, vanadium oxide $\left(\mathrm{V}_{2} \mathrm{O}_{5}\right)$, molybdenum oxide $\left(\mathrm{MoO}_{3}\right)$, and others are used to fabricate efficient MOS sensors [28-37]. To explore the characteristics of both, $\mathrm{n}$ - and p-type semiconductor nanomaterials, MOS sensors have recently been made using $p$-n heterojunction nanostructures, which employ composites of $\mathrm{p}$ - and n-type semiconductors as functional materials to improve sensing characteristics. Thus, several p-n heterojunction nanostructure-based MOS sensors were fabricated and reported in the literature, for instance, $\mathrm{SnO}_{2} / \mathrm{Co}_{3} \mathrm{O}_{4}$, $\mathrm{CuO} / \mathrm{ZnO}, \mathrm{NiO} / \mathrm{ZnO}, \mathrm{CuO} / \mathrm{CuFe}_{2} \mathrm{O}_{4}, \mathrm{SnO}_{2} / \mathrm{CuO}, \mathrm{WO}_{3} / \mathrm{CuO}$, and so on [22-30,38-41]. $\mathrm{CuO} / \mathrm{ZnO}$ nanoparticles demonstrated good selectivity towards $\mathrm{H}_{2} \mathrm{~S}$ gases among heterojunction nanomaterial-based MOS sensors due to the fact that the electron depletion layer on the surface of particles is enlarged by p-n heterojunctions, and the separation of electron-hole carriers increases the active sites of gas-solid reactions on the surface of the material $[5-8,27]$. Several experimental investigations on this $p-n$ heterojunction nanomaterial for $\mathrm{H}_{2} \mathrm{~S}$ sensing have been conducted and reported, however, to the best of our knowledge, no theoretical work has been reported on this subject yet.

In this article, we report the theoretical investigations on the interaction and sensitivity between target sensing gases $\left(\mathrm{H}_{2} \mathrm{~S}\right.$ and $\left.\mathrm{SO}_{2}\right)$ and various quantum clusters of $\mathrm{CuO}-\mathrm{ZnO}$ heterojunction structures. Density functional theory (DFT) computations in the Gaussian 09 software were used for theoretical research. The optimum compositions of the $\mathrm{CuO}$ $\mathrm{ZnO}$ heterojunction structures were observed using a variety of geometric optimizations. Various computations relating to the gas-sensing characteristics were done to properly leverage the $\mathrm{CuO}-\mathrm{ZnO}$ heterojunction structures.

\section{Methods and Computational Details}

Herein, density functional theory (DFT) calculations were performed to scrutinize the $\mathrm{H}_{2} \mathrm{~S}$ and $\mathrm{SO}_{2}$ interaction with the $\mathrm{CuO}-\mathrm{ZnO}$ heterojunction structures. The B3LYP hybrid functional contains exchange and correlation functionals and is based on the exact form of the Vosko-Wilk-Nusair correlation potential [42]. The functional B included the Slater exchange along with corrections involving the gradient of the density $[43,44]$, whereas the correlation functional LYP includes both local and non-local terms [45,46]. Interestingly, the B3LYP/LanL2DZ has been utilized successfully to predict the geometric and electronic properties of various metal oxide $(\mathrm{ZnO}, \mathrm{CuO})$ surfaces [47-49]. In the previous studies, a twenty-four atom $\mathrm{M}_{12} \mathrm{O}_{12}(\mathrm{M}=\mathrm{Zn}, \mathrm{Cu})$ quantum cluster was utilized to simulate $\mathrm{ZnO}$ and $\mathrm{CuO}$ nanomaterials [50-52]. Therefore, in the present study, the $\mathrm{CuO}-\mathrm{ZnO}$ heterojunction was simulated by adopting the $\mathrm{Cu}_{2} \mathrm{Zn}_{10} \mathrm{O}_{12}$ quantum cluster. The B3LYP method was employed to perform all the calculations. The LanL2DZ basis set was utilized for $\mathrm{Cu}$, $\mathrm{Zn}, \mathrm{S}, \mathrm{O}$, and $\mathrm{H}$ atoms. The LanL2DZ pseudopotential was added to $\mathrm{Cu}$ and $\mathrm{Zn}$ atoms. The adsorption energies $\left(\mathrm{E}_{\mathrm{ads}}\right)$ were estimated as:

$$
\mathrm{E}_{\mathrm{ads}}=\mathrm{E}_{\text {adsorbate/substrate }}-\left(\mathrm{E}_{\text {substrate }}+\mathrm{E}_{\text {adsorbate }}\right)
$$

where, $E_{\text {adsorbate/substrate }}, E_{\text {substrate, }}$ and $E_{\text {adsorbate }}$ are the energies of the optimized adsorbatesubstrate complexes, the $\mathrm{Cu}_{2} \mathrm{Zn}_{10} \mathrm{O}_{12}$ cluster, and the free adsorbate gas, respectively. 
The negative adsorption values refer to an exothermic interaction. In other words, the more negative the value of the absorption energy, the more stable the adsorbate-substrate complex.

All the considered structures are fully optimized without any constraints under the following optimization conditions: the force acting on an atom, the root-mean-square of the force, the calculated displacement for the next step and the root-mean-square of the displacement for the next step must be below the cutoff values of $0.129 \mathrm{eV} / \AA, 0.086 \mathrm{eV} / \AA$, $5.29 \times 10^{-3} \AA$. and $3.53 \times 10^{-3} \AA$, respectively, all in atomic units. All the calculations were performed using the Gaussian 09 program [53] and visualized by Gauss View 5, whereas the density of states (DOS) was represented by the Gauss Sum 3.0 program [54]. NBO version 3.1 [55] was used to estimate the atomic charge distribution.

Equation (2) [56-58] shows the dependence of the electrical conductivity $(\sigma)$ on the $E_{g}$

$$
\sigma=\mathrm{AT}^{3 / 2} \exp \left(-\mathrm{E}_{\mathrm{g}} / 2 \mathrm{kT}\right)
$$

where $\mathrm{A}$ is a constant, $\mathrm{k}$ is the Boltzmann constant, and $\mathrm{T}$ is the temperature.

The sensor sensitivity is calculated by the following equation [58]:

$$
S=\left|\exp \left(\frac{E_{g}(I I)-E_{g}(I)}{k T}\right)\right|
$$

where $E_{g}$ (I) and $E_{g}$ (II) are the energy gap value for the substrate and the adsorbatesubstrate complex, respectively.

The recovery time $(\tau)$ is given as [59]:

$$
\tau=v_{\mathrm{o}}^{-1} \exp \left(\frac{-\mathrm{E}_{\mathrm{ads}}}{\mathrm{kT}}\right)
$$

where $v_{\mathrm{o}}$ is the attempt frequency, $\mathrm{k}$ is the Boltzmann constant and $\mathrm{T}$ is the temperature.

\section{Results and Discussion}

\subsection{Geometric Optimization}

Five isomeric structures of the $\mathrm{Cu}_{2} \mathrm{Zn}_{10} \mathrm{O}_{12}$ cluster, labelled as $\mathrm{a}, \mathrm{b}, \mathrm{c}, \mathrm{d}$, and e (see Figure 1) that represent all potential locations for the copper atoms were studied in order to find the global minima structure of the investigated $\mathrm{Cu}_{2} \mathrm{Zn}_{10} \mathrm{O}_{12}$ cluster. Interestingly, it was observed that structure (a) is the most energetically stable structure. Figure 2a shows the fully optimized structures at the optimum spin and represents the energy variations of the structures relative to the most stable structure. Therefore, structure (a) was considered for further calculations. Figure $2 b$ illustrates the energy variations of structure (a) versus the spin of the cluster. Figure 3 demonstrates the density of states as well as the HOMO and LUMO orbital for the most energetically stable structure of the $\mathrm{Cu}_{2} \mathrm{Zn}_{10} \mathrm{O}_{12}$ cluster. It is clear that the HOMO $(\alpha)$ orbital was localized on the $\mathrm{O}$ atoms whereas the LUMO $(\alpha)$ was localized on the $\mathrm{Zn}$ atoms of the cluster. This elucidated that the $\mathrm{O}$ atoms are electron-rich centers and the $\mathrm{Zn}$ atoms are electron-deficient centers. 


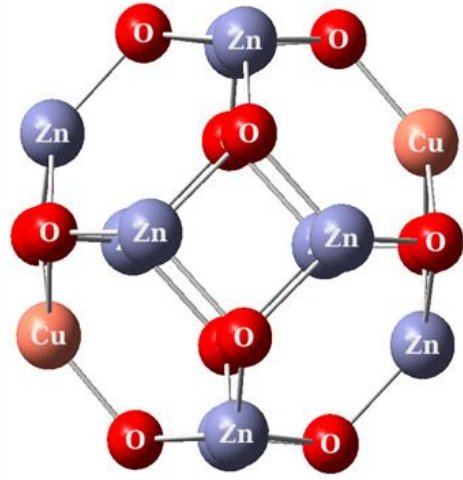

Structure (a)

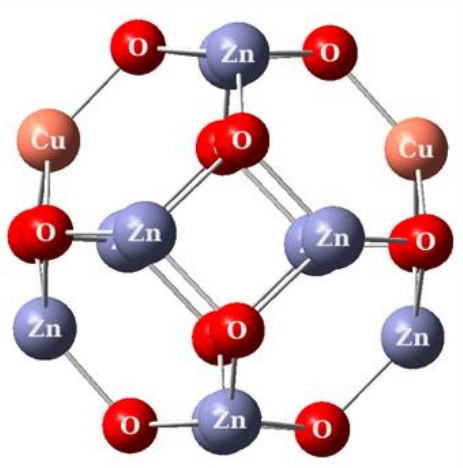

Structure (c)

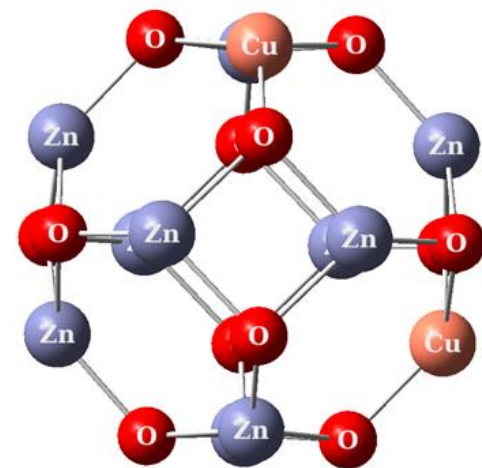

Structure (b)

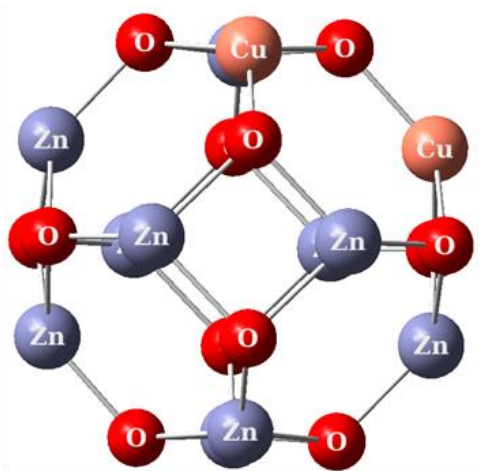

Structure (d)

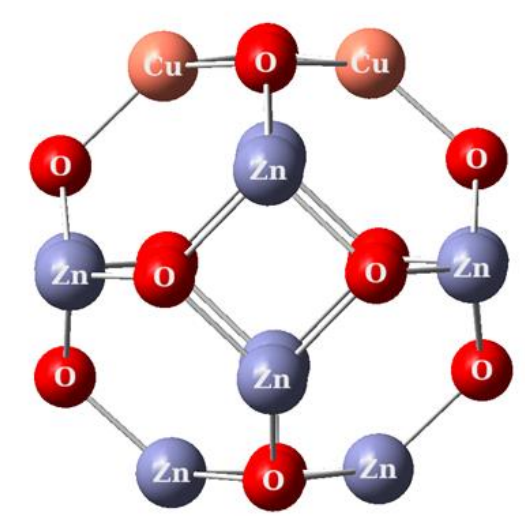

Structure (e)

Figure 1. The isomeric structures of the $\mathrm{Cu}_{2} \mathrm{Zn}_{10} \mathrm{O}_{12}$ cluster. 

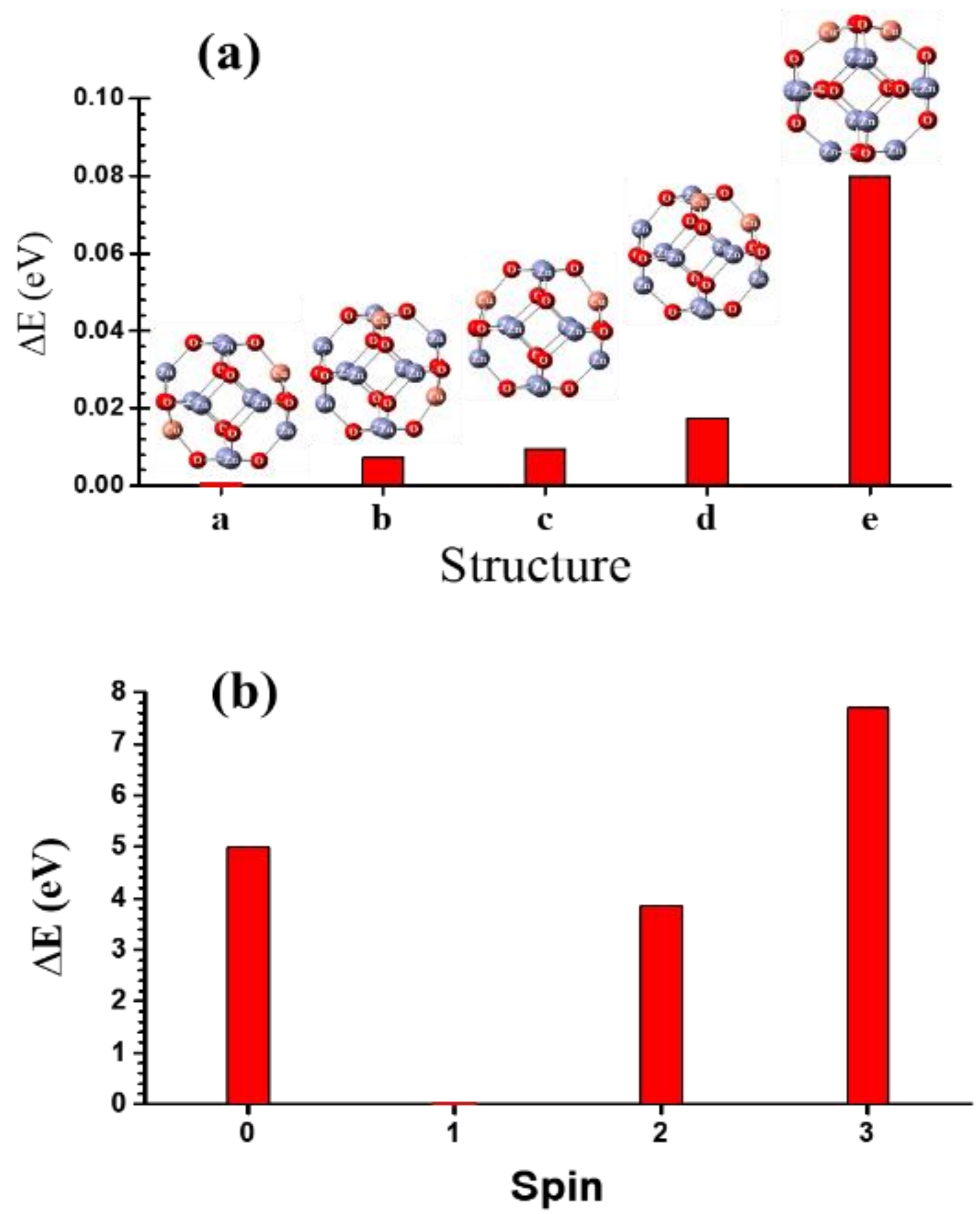

Figure 2. (a) The energy variations $(\Delta \mathrm{E})$ of the structures relative to the most stable structure. The fully optimized structures are inserted. (b) The energy variations $(\Delta \mathrm{E})$ versus the spin of the most stable structure. 


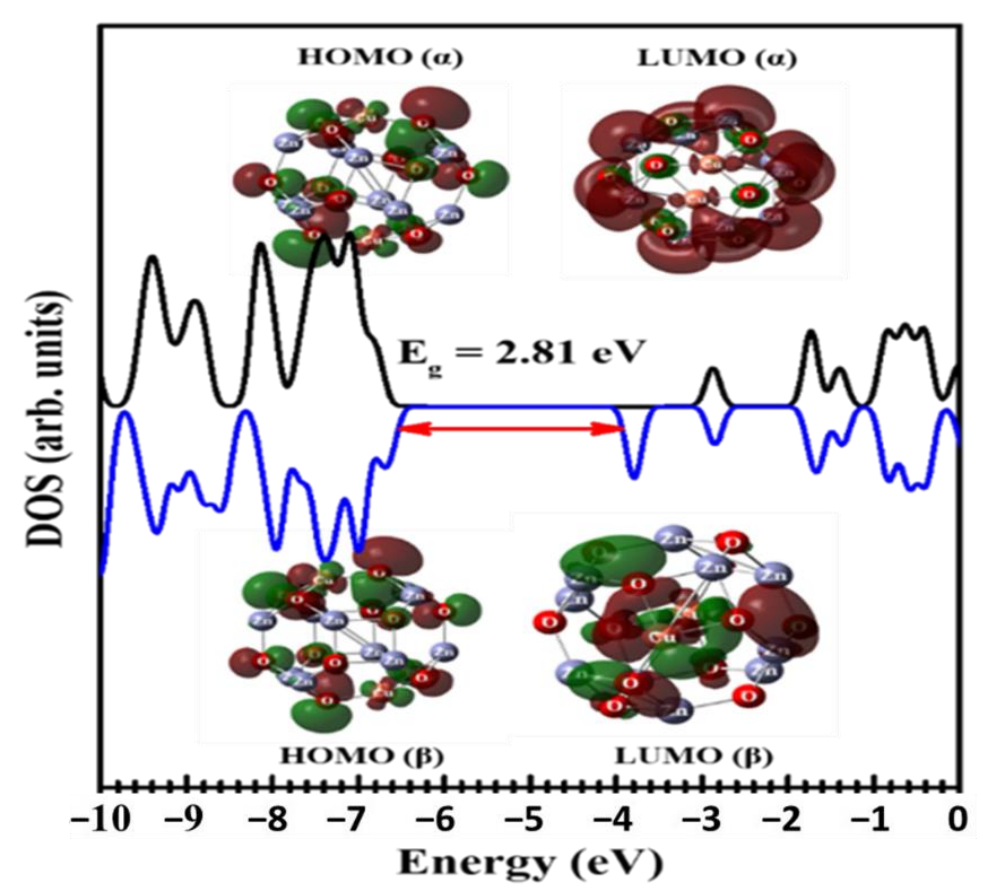

Figure 3. DOS for the $\mathrm{Cu}_{2} \mathrm{Zn}_{10} \mathrm{O}_{12}$ substrate cluster. HOMO and LUMO are inserted.

Furthermore, the copper atoms contributed oxygen atoms to the $\operatorname{HOMO}(\beta)$, whereas the LUMO $(\beta)$ was localized mainly on the $\mathrm{Cu}$ atoms. The contribution of $\mathrm{Cu}$ atoms in both HOMO and LUMO may be owing to the incompletely filled d orbitals. Moreover, the $\mathrm{Cu}_{2} \mathrm{Zn}_{10} \mathrm{O}_{12}$ cluster was a semiconductor with a HOMO-LUMO energy gap ( $\mathrm{E}_{\mathrm{g}}$ ) of $2.81 \mathrm{eV}$. The natural bond orbitals (NBO) showed that the copper atoms had positive charges of $0.96 \mathrm{lel}$, the zinc atoms had positive charges ranging from 1.42 to $1.44 \mathrm{lel}$, and the oxygen atoms carried negative charges ranging from -1.23 to -1.42 le l. Moreover, the dipole moment of the $\mathrm{Cu}_{2} \mathrm{Zn}_{10} \mathrm{O}_{12}$ was 0.46 Debye.

\subsection{Interaction of Gases with the $\mathrm{Cu}_{2} \mathrm{Zn}_{10} \mathrm{O}_{12}$ Structure}

Additionally, the $\mathrm{H}_{2} \mathrm{~S}$ and $\mathrm{SO}_{2}$ gases were optimized. For the $\mathrm{H}_{2} \mathrm{~S}$ molecule, the $\mathrm{H}-\mathrm{S}$ bond was $1.377 \AA$ and the $\mathrm{H}-\mathrm{S}-\mathrm{H}$ angle equaled $94.2^{\circ}$. The charges on the $\mathrm{S}$ and $\mathrm{H}$ atoms were -0.270 and $0.135|\mathrm{e}|$, respectively, which were consistent with the reported literature [60-62]. For the $\mathrm{SO}_{2}$ molecule, the S-O bond was $1.610 \AA$ and the O-S-O angle equaled $112.8^{\circ}$. The $\mathrm{S}$ and $\mathrm{O}$ atoms carried charges of 1.32 and $-0.66 \mathrm{le} \mathrm{I}$, respectively, which agreed with previous studies [63-65]. The dipole moment values for $\mathrm{SO}_{2}$ and $\mathrm{H}_{2} \mathrm{~S}$ were 2.79 and 1.76 Debye. Because the high dipole moment of a molecule indicates a high reactivity with the surrounding medium [66], one can expect that the reactivity of the $\mathrm{SO}_{2}$ molecule is higher than that of the $\mathrm{H}_{2} \mathrm{~S}$ molecule.

To understand the effect of the $\mathrm{Cu}_{2} \mathrm{Zn}_{10} \mathrm{O}_{12}$ cluster sensing features on $\mathrm{H}_{2} \mathrm{~S}$ and $\mathrm{SO}_{2}$ gases, the characteristics of adsorbate-substrate interaction were scrutinized. For that, the adsorbates $\left(\mathrm{H}_{2} \mathrm{~S}\right.$ and $\left.\mathrm{SO}_{2}\right)$, substrate $\left(\mathrm{Cu}_{2} \mathrm{Zn}_{10} \mathrm{O}_{12}\right)$, and the adsorbate-substrate complexes $\left(\mathrm{H}_{2} \mathrm{~S} / \mathrm{Cu}_{2} \mathrm{Zn}_{10} \mathrm{O}_{12}\right.$ and $\left.\mathrm{SO}_{2} / \mathrm{Cu}_{2} \mathrm{Zn}_{10} \mathrm{O}_{12}\right)$ were fully optimized without any constraints. Since the adsorbed $\mathrm{H}_{2} \mathrm{~S}$ (or $\mathrm{SO}_{2}$ ) molecule can interact via its $\mathrm{S}$ atom and $\mathrm{H}$ (or $\mathrm{O}$ ) atom with the $\mathrm{Cu}, \mathrm{Zn}$, and $\mathrm{O}$ sites, six adsorption modes representing the previous possibilities were investigated (Figure 4). The adsorption energies for the investigated complexes were calculated by Equation (1). 


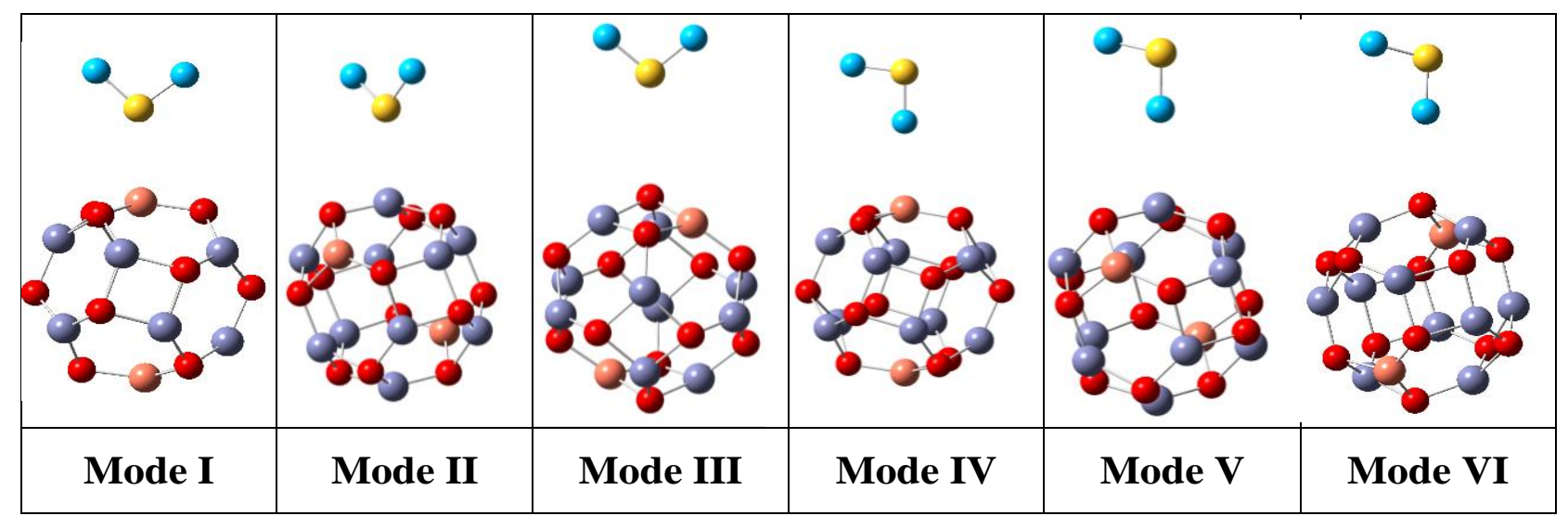

Figure 4. The non-optimized adsorbate-substrate adsorption modes of $\mathrm{H}_{2} \mathrm{~S} / \mathrm{Cu}_{2} \mathrm{Zn}_{10} \mathrm{O}_{12}$ and $\mathrm{SO}_{2} / \mathrm{Cu}_{2} \mathrm{Zn}_{10} \mathrm{O}_{12}$ complexes. The cyan atom represents $\mathrm{H}$ or $\mathrm{O}$ atoms.

Figures 5 and 6 show the optimized $\mathrm{H}_{2} \mathrm{~S} / \mathrm{Cu}_{2} \mathrm{Zn}_{10} \mathrm{O}_{12}$ and $\mathrm{SO}_{2} / \mathrm{Cu}_{2} \mathrm{Zn}_{10} \mathrm{O}_{12}$ complexes, respectively, with adsorption energies. It is worth mentioning that the adsorption heat that is more negative than $-0.2 \mathrm{eV}$ specifies the chemisorptions $[67,68]$.

\begin{tabular}{|c|c|c|c|c|c|}
\hline $0 \quad 0$ & 0 0 & & & 0 & \\
\hline $0_{0}^{0}$ & 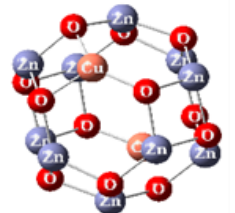 & 8 & 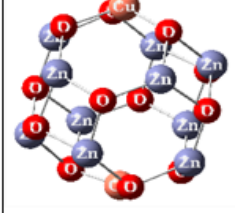 & 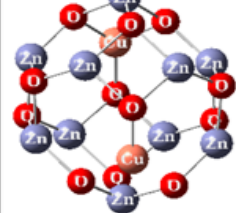 & 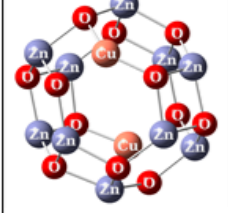 \\
\hline Mode I & Mode II & Mode III & Mode IV & Mode V & Mode VI \\
\hline$E_{\mathrm{ads}}=-0.245$ & $E_{\text {ads }}=-0.084$ & $\mathrm{E}_{\mathrm{ads}}=-2.640$ & $E_{\text {ads }}=-\mathbf{0 . 6 3 7}$ & $\mathrm{E}_{\mathrm{ads}}=-0.928$ & $\mathrm{E}_{\mathrm{ads}}=-0.939$ \\
\hline
\end{tabular}

Figure 5. The optimized complexes with adsorption energies in $\mathrm{eV}$ of $\mathrm{H}_{2} \mathrm{~S} / \mathrm{Cu}_{2} \mathrm{Zn}_{10} \mathrm{O}_{12}$ complexes.

\begin{tabular}{|c|c|c|c|c|c|}
\hline 00 & 0 & & & & \\
\hline $\int_{0}^{0} 0_{0}^{0}$ & 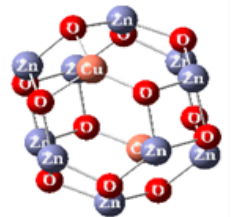 & 8 & 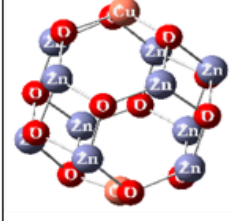 & 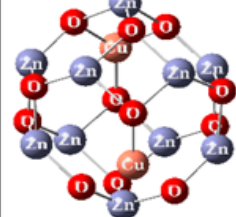 & \%० \\
\hline Mode I & Mode II & Mode III & Mode IV & Mode V & Mode VI \\
\hline $\mathrm{E}_{\mathrm{ads}}=-0.245$ & $E_{\text {ads }}=-0.084$ & $\mathrm{E}_{\mathrm{ads}}=-2.640$ & $E_{\text {ads }}=-\mathbf{0 . 6 3 7}$ & $\mathrm{E}_{\mathrm{ads}}=-0.928$ & $\mathrm{E}_{\mathrm{ads}}=-\mathbf{0 . 9 3 9}$ \\
\hline
\end{tabular}

Figure 6. The optimized complexes with adsorption energies in $\mathrm{eV}$ of $\mathrm{SO}_{2} / \mathrm{Cu}_{2} \mathrm{Zn}_{10} \mathrm{O}_{12}$ complexes.

It is clear that the adsorption for $\mathrm{SO}_{2} / \mathrm{Cu}_{2} \mathrm{Zn}_{10} \mathrm{O}_{12}$ and $\mathrm{H}_{2} \mathrm{~S} / \mathrm{Cu}_{2} \mathrm{Zn}_{10} \mathrm{O}_{12}$ is chemisorption for all the adsorption modes except for $\mathrm{SO}_{2} / \mathrm{Cu}_{2} \mathrm{Zn}_{10} \mathrm{O}_{12}$ mode II and $\mathrm{H}_{2} \mathrm{~S} / \mathrm{Cu}_{2} \mathrm{Zn}_{10} \mathrm{O}_{12}$ mode III. This indicates a strong interaction between the investigated gas and the cluster, which explains the sensitivity of the cluster to the considered gases. Assuming that 
the adsorption modes with the highest released adsorption energies are the most likely interaction, we will pay attention to $\mathrm{SO}_{2} / \mathrm{Cu}_{2} \mathrm{Zn}_{10} \mathrm{O}_{12}$ mode III and $\mathrm{H}_{2} \mathrm{~S} / \mathrm{Cu}_{2} \mathrm{Zn}_{10} \mathrm{O}_{12}$ mode $\mathrm{V}$.

Table 1 summarizes the adsorption properties, whereas Figure 7 represents the density of states and the optimized geometrical structures for the considered modes.

Table 1. The adsorption properties for $\mathrm{SO}_{2} / \mathrm{Cu}_{2} \mathrm{Zn}_{10} \mathrm{O}_{12}$ and $\mathrm{H}_{2} \mathrm{~S} / \mathrm{Cu}_{2} \mathrm{Zn}_{10} \mathrm{O}_{12}$. The adsorption energy $\left(\mathrm{E}_{\mathrm{ads}}, \mathrm{eV}\right)$, HOMO-LUMO gap $\left(\mathrm{E}_{\mathrm{g}}, \mathrm{eV}\right)$, percentage change in HOMO-LUMO gap $\left(\Delta \mathrm{E}_{\mathrm{g}}, \%\right)$, NBO charges $(\mathrm{Q}, \mathrm{eV})$, and dipole moment $(\mu$, Debye).

\begin{tabular}{ccccccccc}
\hline Adsorption Mode & $\mathbf{E}_{\text {ads }}$ & $\mathbf{E}_{\mathbf{g}}$ & $\Delta \mathbf{E}_{\mathbf{g}} \%$ & $\mathbf{Q}_{\mathbf{S}}$ & $\mathbf{Q}_{\mathbf{I}}$ & $\mathbf{Q}_{\text {II }}$ & $\mathbf{Q}_{\text {gas }}$ & $\mu$ \\
\hline $\mathrm{SO}_{2} / \mathrm{Cu}_{2} \mathrm{Zn}_{10} \mathrm{O}_{12}$ & -2.64 & 2.67 & -4.98 & 1.62 & -0.96 & -0.97 & -0.31 & 3.35 \\
$\mathrm{H}_{2} \mathrm{~S}_{\mathrm{Cu}_{2} \mathrm{Zn}_{10} \mathrm{O}_{12}}$ & -1.58 & 1.60 & -43.02 & -0.73 & 0.54 & 0.14 & -0.05 & 5.75 \\
\hline
\end{tabular}
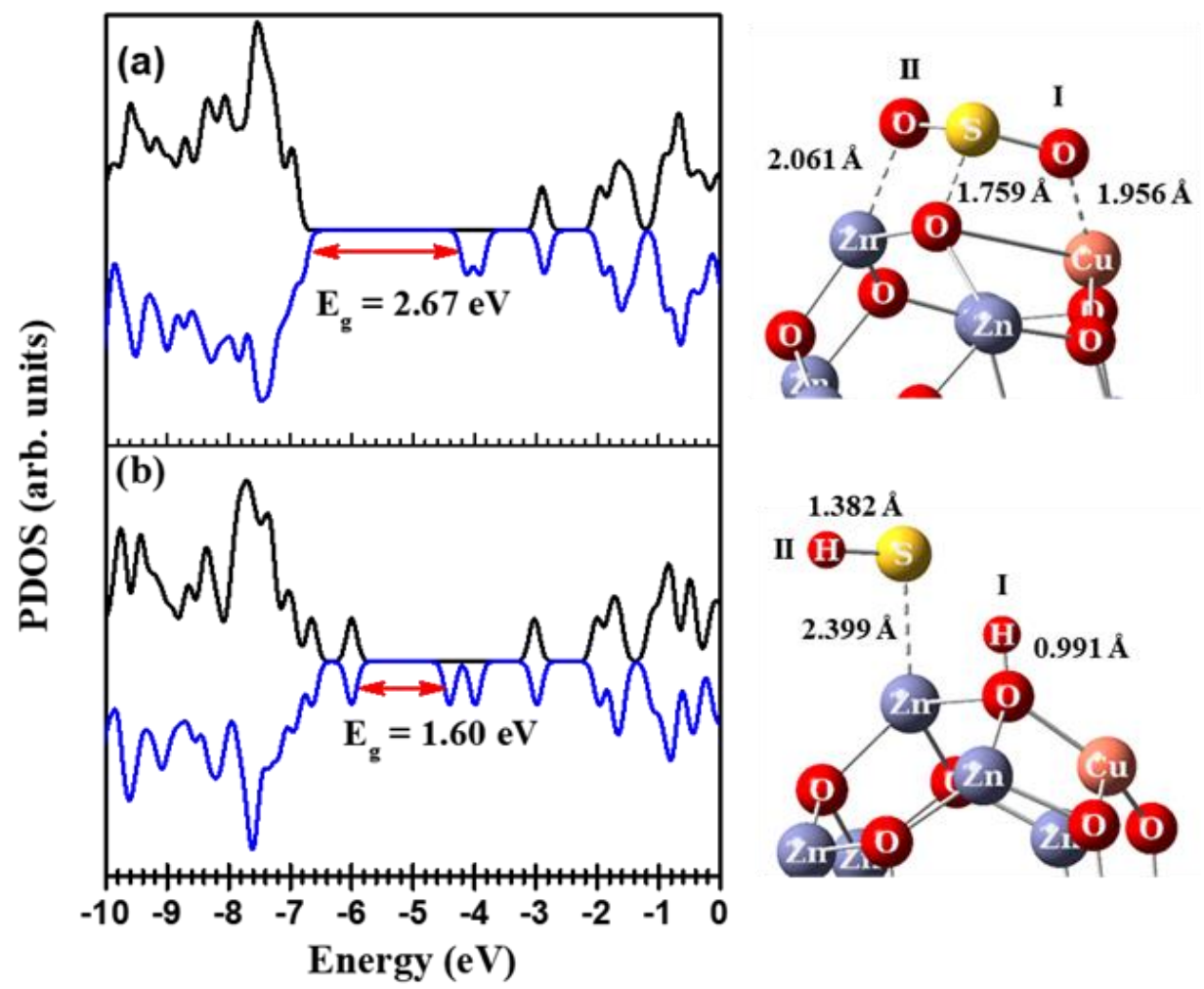

Figure 7. The DOS and the optimized structures for (a) $\mathrm{SO}_{2} / \mathrm{Cu}_{2} \mathrm{Zn}_{10} \mathrm{O}_{12}$ (mode III) and (b) $\mathrm{H}_{2} \mathrm{~S} / \mathrm{Cu}_{2} \mathrm{Zn}_{10} \mathrm{O}_{12}$ (mode $\mathrm{V}$ ).

As clearly shown in Table 1 for the considered $\mathrm{SO}_{2} / \mathrm{Cu}_{2} \mathrm{Zn}_{10} \mathrm{O}_{12}$ cluster, the positive charge of the $\mathrm{S}$ atom of the $\mathrm{SO}_{2}$ molecule rose to 1.62 le I rather than 1.314 le l for the free $\mathrm{SO}_{2}$ molecule, whereas the negative charges of the $\mathrm{O}$ atoms increased to -0.96 and $-0.97|\mathrm{e}|$ rather than $-0.66|\mathrm{e}|$ for the free $\mathrm{SO}_{2}$ molecule. This confirms that a charge transfer occurred from the $\mathrm{S}$ atom to the substrate and from the substrate to the $\mathrm{O}$ atoms of the $\mathrm{SO}_{2}$ molecule. As a result, three bonds were formed between the $\mathrm{SO}_{2}$ molecule and the cluster as shown in Figure 7a. These bonds are the $\mathrm{Zn}-\mathrm{O}$ bond, S-O bond, and $\mathrm{Cu}-\mathrm{O}$ bond, and they are dashed in Figure 7a. The first, second and the third bonds were formed between $\mathrm{Zn}, \mathrm{O}, \mathrm{Cu}$ atoms from the cluster and $\mathrm{O}(\mathrm{II}), \mathrm{S}$, and $\mathrm{O}(\mathrm{I})$ atoms from the $\mathrm{SO}_{2}$ molecule, respectively. This explains the high adsorption heat of the $\mathrm{SO}_{2} / \mathrm{Cu}_{2} \mathrm{Zn}_{10} \mathrm{O}_{12}$ cluster. To confirm the formation of such bonds, the Mulliken overlap population, as well as the bond order, was calculated for the suggested bonds and is tabulated in Table 2. The small value for the overlap population, close to zero, declares a non-significant interaction between the electronic populations of the two atoms, whereas the high value refers to 
a high degree of interaction [55,69]. It is noteworthy that high overlap population values of $1.57,9.96$ and 1.24 as well as high bond order values of $0.97,0.54$, and 1.03 were recorded for the $\mathrm{Zn}-\mathrm{O}$ bond, $\mathrm{S}-\mathrm{O}$ bond, and $\mathrm{Cu}-\mathrm{O}$ bond, respectively. This indicates that a strong adsorbate-substrate interaction occurred.

Table 2. Overlap population and bond order analysis for the proposed bonds in the $\mathrm{SO}_{2} / \mathrm{Cu}_{2} \mathrm{Zn}_{10} \mathrm{O}_{12}$ complex.

\begin{tabular}{ccc}
\hline Bond & Overlap Pop. & Bond Order \\
\hline $\mathrm{Zn} \mathrm{O}$ & -1.573 & -0.974 \\
$\mathrm{~S} \mathrm{O}$ & -9.963 & -0.536 \\
$\mathrm{Cu} \mathrm{O}$ & -1.239 & 1.026 \\
\hline
\end{tabular}

On the other hand, for the considered $\mathrm{H}_{2} \mathrm{~S} / \mathrm{Cu}_{2} \mathrm{Zn}_{10} \mathrm{O}_{12}$ cluster, due to the adsorption, the $\mathrm{H}_{2} \mathrm{~S}$ dissociated into two fragments, $\mathrm{HS}^{-}$and $\mathrm{H}^{+}$. The $\mathrm{HS}^{-}$fragment was bounded to the $\mathrm{Zn}$ site of the cluster via the $\mathrm{S}$ atom. As a result, the negative charge of the $\mathrm{S}$ atom rose to $-0.73 \mathrm{I}$ e | rather than $-0.27 \mathrm{I} \mid \mathrm{I}$ for the free $\mathrm{H}_{2} \mathrm{~S}$ molecule. This means a charge transfer occurred from the substrate cluster to the $\mathrm{S}$ atom. Although the $\mathrm{H}^{+}$fragment was bounded to an $\mathrm{O}$ site of the cluster and a charge transfer occurred from the $\mathrm{H}$ to the substrate cluster, the charge of the positive hydrogen atom rose to 0.54 Iel rather than $0.14 \mathrm{I} \mathrm{e} \mathrm{I}$ in the free $\mathrm{H}_{2} \mathrm{~S}$ molecule. In other words, there was charge donation, and charge back-donation occurred between the adsorbed gaseous molecule and the substrate for both $\mathrm{SO}_{2} / \mathrm{Cu}_{2} \mathrm{Zn}_{10} \mathrm{O}_{12}$ and $\mathrm{H}_{2} \mathrm{~S} / \mathrm{Cu}_{2} \mathrm{Zn}_{10} \mathrm{O}_{12}$. Consequently, charges redistribution occurred and as a result, the dipole moment rose to 3.35 and 5.75 Debye, respectively. This led to a decrease in the HOMO-LUMO gap $\left(\mathrm{E}_{\mathrm{g}}\right)$ by $4.98 \%$ and $43.02 \%$ as shown in the density of the state spectra for $\mathrm{SO}_{2} / \mathrm{Cu}_{2} \mathrm{Zn}_{10} \mathrm{O}_{12}$ and $\mathrm{H}_{2} \mathrm{~S} / \mathrm{Cu}_{2} \mathrm{Zn}_{10} \mathrm{O}_{12}$, respectively, with regards to the bare cluster (see Figure 7). Since, the electrical conductivity $(\sigma)$ depended on the $\mathrm{E}_{\mathrm{g}}$ obeying Equation (2), the adsorption of $\mathrm{SO}_{2}$ and $\mathrm{H}_{2} \mathrm{~S}$ gases decreased the electrical conductivity of the $\mathrm{Cu}_{2} \mathrm{Zn}_{10} \mathrm{O}_{12}$ cluster. Therefore, the $\mathrm{Cu}_{2} \mathrm{Zn}_{10} \mathrm{O}_{12}$ cluster was sensitive to the examined gases.

It is known that the sensor sensitivity was affected by the $\mathrm{E}_{\mathrm{g}}$ as seen in Equation (3). Therefore, the sensitivity of the $\mathrm{Cu}_{2} \mathrm{Zn}_{10} \mathrm{O}_{12}$ cluster toward the investigated gases is demonstrated in Figure 8. It is clear that the $\mathrm{Cu}_{2} \mathrm{Zn}_{10} \mathrm{O}_{12}$ cluster was more sensitive to the $\mathrm{H}_{2} \mathrm{~S}$ gas than $\mathrm{SO}_{2}$ gas. Furthermore, the sensor action was prominently dependent on the recovery time $(\tau)$. Equation (4) shows that the $\tau$ increased as the released adsorption energy $\left(\mathrm{E}_{\mathrm{ads}}\right)$ increased (more negative). Table 2 shows that the $\mathrm{E}_{\mathrm{ads}}$ values for $\mathrm{SO}_{2} / \mathrm{Cu}_{2} \mathrm{Zn}_{10} \mathrm{O}_{12}$ and $\mathrm{H}_{2} \mathrm{~S} / \mathrm{Cu}_{2} \mathrm{Zn}_{10} \mathrm{O}_{12}$ were -2.640 and $-1.576 \mathrm{eV}$, respectively. Therefore, the $\mathrm{Cu}_{2} \mathrm{Zn}_{10} \mathrm{O}_{12}$ cluster exhibited a higher and faster response-recovery time to $\mathrm{H}_{2} \mathrm{~S}$ than $\mathrm{SO}_{2}$.

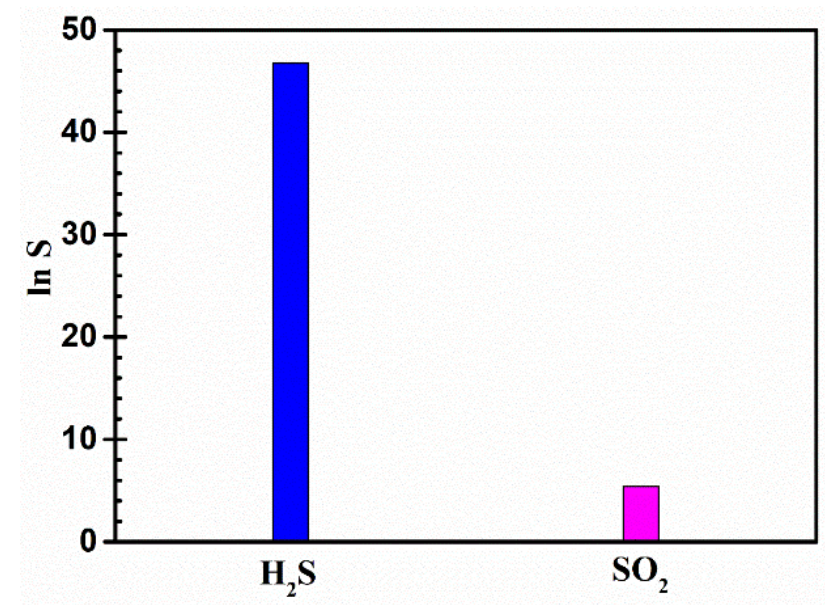

Figure 8. Sensitivity $(\mathrm{S})$ of the $\mathrm{Cu}_{2} \mathrm{Zn}_{10} \mathrm{O}_{12}$ cluster towards the $\mathrm{H}_{2} \mathrm{~S}$ and $\mathrm{SO}_{2}$ gases. 


\section{Conclusions}

In conclusion, the $\mathrm{H}_{2} \mathrm{~S}$ and $\mathrm{SO}_{2}$ interaction with the $\mathrm{CuO}-\mathrm{ZnO}$ heterojunction structures were investigated utilizing DFT calculations at the B3LYP/LanL2DZ level of theory. The $\mathrm{CuO}-\mathrm{ZnO}$ heterojunction was simulated by the $\mathrm{Cu}_{2} \mathrm{Zn}_{10} \mathrm{O}_{12}$ quantum cluster. Six adsorption modes were investigated. The calculated adsorption energies for the $\mathrm{H}_{2} \mathrm{~S}$ and $\mathrm{SO}_{2}$ reached -1.57 and $-2.64 \mathrm{eV}$, respectively, which revealed the strong interaction between the investigated gases and the $\mathrm{Cu}_{2} \mathrm{Zn}_{10} \mathrm{O}_{12}$ cluster. Although the $\mathrm{SO}_{2}$ molecule formed three bonds with the $\mathrm{Cu}_{2} \mathrm{Zn}_{10} \mathrm{O}_{12}$ cluster, the $\mathrm{H}_{2} \mathrm{~S}$ molecule dissociated into $\mathrm{HS}^{-}$and $\mathrm{H}^{+}$, which bound to the $\mathrm{Zn}$ and $\mathrm{O}$ sites of the $\mathrm{Cu}_{2} \mathrm{Zn}_{10} \mathrm{O}_{12}$ cluster. This interaction led to a decrease in the HOMO-LUMO gap $\left(\mathrm{E}_{\mathrm{g}}\right)$ of the $\mathrm{Cu}_{2} \mathrm{Zn}_{10} \mathrm{O}_{12}$ cluster by $4.98 \%$ and $43.02 \%$ for $\mathrm{SO}_{2}$ and $\mathrm{H}_{2} \mathrm{~S}$, respectively. Therefore, the $\mathrm{Cu}_{2} \mathrm{Zn}_{10} \mathrm{O}_{12}$ cluster was more sensitive to the $\mathrm{H}_{2} \mathrm{~S}$ gas than the $\mathrm{SO}_{2}$ gas. Furthermore, the $\mathrm{Cu}_{2} \mathrm{Zn}_{10} \mathrm{O}_{12}$ cluster exhibited higher and faster response-recovery time to $\mathrm{H}_{2} \mathrm{~S}$ than $\mathrm{SO}_{2}$. Our present results indicate that the $\mathrm{CuO}-\mathrm{ZnO}$ heterojunction can be a potential nanomaterial for the detection of $\mathrm{H}_{2} \mathrm{~S}$ and $\mathrm{SO}_{2}$ gases.

Author Contributions: Conceptualization, H.A. (Hasan Albargi), H.Y.A., H.M.B. and A.U.; methodology, H.A. (Hasan Albargi), H.Y.A., H.M.B. and A.U.; software, H.Y.A., H.M.B.; validation, H.A. (Hasan Albargi), H.Y.A., H.M.B., H.A. (Hassan Algadi), and A.U.; formal analysis, H.A. (Hasan Albargi), H.Y.A., H.M.B., H.A. (Hassan Algadi), and A.U.; investigation, H.Y.A. and H.M.B.; resources, H.Y.A. and H.M.B.; data curation, H.Y.A. and H.M.B.; writing-original draft preparation, H.A. (Hasan Albargi), H.Y.A., H.M.B., H.A. (Hassan Algadi), and A.U.; writing-review and editing, H.A. (Hasan Albargi), H.Y.A., H.M.B., H.A. (Hassan Algadi), and A.U.; visualization, H.Y.A. and H.M.B.; supervision, H.Y.A., A.U. and H.M.B.; project administration, H.Y.A. and H.M.B.; funding acquisition, H.A. (Hasan Albargi), H.Y.A., H.M.B. and A.U. All authors have read and agreed to the published version of the manuscript.

Funding: This work was funded by the Ministry of Education, Kingdom of Saudi Arabia through a grant (PCSED-012-18) under the Promising Centre for Sensors and Electronic Devices (PCSED) at Najran University, Kingdom of Saudi Arabia.

Institutional Review Board Statement: Not Applicable.

Informed Consent Statement: Not Applicable.

Data Availability Statement: All data is included in the manuscript.

Acknowledgments: Authors would like to acknowledge the support of the Ministry of Education, Kingdom of Saudi Arabia for this research through a grant (PCSED-012-18) under the Promising Centre for Sensors and Electronic Devices (PCSED) at Najran University, Kingdom of Saudi Arabia.

Conflicts of Interest: The authors declare no conflict of interest.

\section{References}

1. Umar, A.; Alduraibi, M.; Al-Dossary, O. NOx Gas Sensing Properties of Fe-Doped ZnO Nanoparticles. Sci. Adv. Mater. 2020, 12, 908-914. [CrossRef]

2. Umar, A.; Alduraibi, M.; Al-Dossary, O. Development of Ethanol Gas Sensor Using $\alpha-\mathrm{Fe}_{2} \mathrm{O}_{3}$ Nanocubes Synthesized by Hydrothermal Process. J. Nanoelectron. Optoelectron. 2020, 15, 59-64. [CrossRef]

3. Vijeata, A.; Chaudhary, G.R.; Umar, A.; Chaudhary, S. Distinctive Solvatochromic Response of Fluorescent Carbon Dots Derived from Different Components of Aegle Marmelos Plant. Eng. Sci. 2021, 15, 197-209. [CrossRef]

4. Umar, A.; Algadi, H.; Kumar, R.; Akhtar, M.S.; Ibrahim, A.A.; Albargi, H.; Alhamami, M.A.M.; Alsuwian, T.; Zeng, W. Ultrathin Leaf-Shaped CuO Nanosheets Based Sensor Device for Enhanced Hydrogen Sulfide Gas Sensing Application. Chemosensors 2021, 9, 221. [CrossRef]

5. Wang, X.; Li, S.; Xie, L.; Li, X.; Lin, D.; Zhu, Z. Low-temperature and highly sensitivity H2S gas sensor based on ZnO/CuO composite derived from bimetal metal-organic frameworks. Ceram. Int. 2020, 46, 15858-15866. [CrossRef]

6. Park, S.; Kim, S.-H.; Kheel, H.; Hyun, S.K.; Jin, C.; Lee, C. Enhanced $\mathrm{H}_{2} \mathrm{~S}$ gas sensing performance of networked CuO-ZnO composite nanoparticle sensor. Mater. Res. Bull. 2016, 82, 130-135. [CrossRef]

7. Xu, Q.; Ju, D.; Zhang, Z.; Yuan, S.; Zhang, J.; Xu, H.; Cao, B. Near room-temperature triethylamine sensor constructed with $\mathrm{CuO} / \mathrm{ZnO}$ P-N heterostructural nanorods directly on flat electrode. Sens. Actuators Chem. 2015, 225, 16-23. [CrossRef]

8. Zhou, M.; Chen, X.; Zhang, L.; Zeng, W. High Performance Novel Gas Sensor Device for Site Environmental Protection Using $\mathrm{Ti}_{0.5} \mathrm{Sn}_{0.5} \mathrm{O}_{2}$ Nanomaterials. J. Nanoelectron. Optoelectron. 2020, 15, 1423-1428. [CrossRef] 
9. Cheng, H.; Zhou, Z.; Qin, D.; Huang, W.; Feng, J.; Tang, T.; Hu, G.; Li, L. Electrochemical Sensor Based on Electrospun Three-Dimensional Carbon Nanofibers to Determine Trace Levels of Cu(II). Sci. Adv. Mater. 2020, 12, 693-700. [CrossRef]

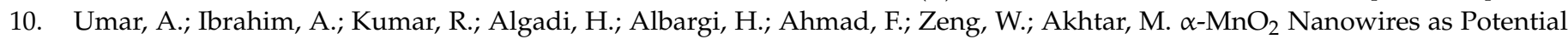
Scaffolds for a High-Performance Formaldehyde Gas Sensor Device. Coatings 2021, 11, 860. [CrossRef]

11. Wu, C.; Ye, G.; Qi, L.; Wang, Y.; Yuan, C.; Zhang, L. Novel ZnO Sensor and Gas Detection Performance in Tunnel Construction. J. Nanoelectron. Optoelectron. 2020, 15, 1114-1119. [CrossRef]

12. Umar, A.; Ibrahim, A.A.; Algadi, H.; Albargi, H.; Alsairi, M.A.; Wang, Y.; Akbar, S. Enhanced $\mathrm{NO}_{2}$ gas sensor device based on supramolecularly assembled polyaniline/silver oxide/graphene oxide composites. Ceram. Int. 2021, 47, 25696-25707. [CrossRef]

13. Qi, L.; Pan, Y. A Novel Sensor Apply in Detection of Indoor Air. Sci. Adv. Mater. 2020, 12, 282-288. [CrossRef]

14. Zhou, X.; Deng, D.; Zhang, L. A Novel Flower Like Tin Oxides Sensor and Indoor Air Sensing Applications. J. Nanoelectron. Optoelectron. 2020, 15, 1171-1176. [CrossRef]

15. Wang, G.; Yayalikun, N.; Mamat, X.; Li, Y.; Hu, X.; Wang, P.; Xin, X.; Hu, G. Highly Sensitive Electrochemical Sensor for the Detection of Chloramphenicol Based on Biomass Derived Porous Carbon. Sci. Adv. Mater. 2020, 12, 376-382. [CrossRef]

16. Umar, A.; Ibrahim, A.A.; Algadi, H.; Nakate, U.T.; Choudhury, S.P.; Alsuwian, T.; Albargi, H.; Alsaiari, M.A.; Baskoutas, S. Selective ethanol gas sensing performance of flower-shaped $\mathrm{CuO}$ composed of thin nanoplates. J. Mater. Sci. Mater. Electron. 2021, 1-15. [CrossRef]

17. Zhu, H.; Wang, K.; Zhang, F.; Chen, W.; Wang, Z.; Zhu, X.; Yin, J.; Li, D.; Zhu, R.; Li, K. A Novel Indoor Air Sensor Apply in Detecting Formaldehyde. J. Nanoelectron. Optoelectron. 2020, 15, 859-863. [CrossRef]

18. Umar, A.; Ibrahim, A.A.; Kumar, R.; Algadi, H.; Albargi, H.; Alsairi, M.A.; Alhmami, M.A.; Zeng, W.; Ahmed, F.; Akbar, S. CdO-ZnO nanorices for enhanced and selective formaldehyde gas sensing applications. Environ. Res. 2021, $200,111377$. [CrossRef]

19. Aleksandrova, M.; Tsanev, T.; Gupta, A.; Singh, A.K.; Dobrikov, G.; Videkov, V. Sensing Ability of Ferroelectric Oxide Nanowires Grown in Templates of Nanopores. Materials 2020, 13, 1777. [CrossRef]

20. Chowdhury, N.K.; Bhowmik, B. Micro/nanostructured gas sensors: The physics behind the nanostructure growth, sensing and selectivity mechanisms. Nanoscale Adv. 2020, 3, 73-93. [CrossRef]

21. Kim, S.; Cho, Y.T. Replication and Surface Treatment of Micro Pattern Generated by Entanglement of Nanowires. Sci. Adv. Mater. 2020, 12, 403-406. [CrossRef]

22. Das, S.; Girija, K.; Debnath, A.; Vatsa, R. Enhanced $\mathrm{NO}_{2}$ and $\mathrm{SO}_{2}$ sensor response under ambient conditions by polyol synthesized Ni doped SnO2 nanoparticles. J. Alloys Compd. 2020, 854, 157276. [CrossRef]

23. Tyagi, P.; Sharma, A.; Tomar, M.; Gupta, V. Metal oxide catalyst assisted $\mathrm{SnO}_{2}$ thin film based $\mathrm{SO}_{2}$ gas sensor. Sensors Actuators B: Chem. 2016, 224, 282-289. [CrossRef]

24. Zhou, Q.; Zeng, W.; Chen, W.; Xu, L.; Kumar, R.; Umar, A. High sensitive and low-concentration sulfur dioxide $\left(\mathrm{SO}_{2}\right)$ gas sensor application of heterostructure NiO-ZnO nanodisks. Sens. Actuators B Chem. 2019, 298, 126870. [CrossRef]

25. Lee, B.J.; Efremov, A.; Nam, Y.; Kwon, K.-H. On the Control of Plasma Chemistry and Silicon Etching Kinetics in Ternary HBr + $\mathrm{Cl}_{2}+\mathrm{O}_{2}$ Gas System: Effects of $\mathrm{HBr} / \mathrm{O}_{2}$ and $\mathrm{Cl}_{2} / \mathrm{O}_{2}$ Mixing Ratios. Sci. Adv. Mater. 2020, 12, 628-640. [CrossRef]

26. Zeng, Q.; Zhang, L. A Novel $\mathrm{NO}_{2}$ Sensor Applied in Natural Protected Area. J. Nanoelectron. Optoelectron. 2020, 15, 19-23. [CrossRef]

27. Na, H.-B.; Zhang, X.-F.; Zhang, M.; Deng, Z.-P.; Cheng, X.-L.; Huo, L.-H.; Gao, S. A fast response/recovery ppb-level H2S gas sensor based on porous $\mathrm{CuO} / \mathrm{ZnO}$ heterostructural tubule via confined effect of absorbent cotton. Sens. Actuators B Chem. 2019, 297, 126816. [CrossRef]

28. Gu, H.; Huang, X.; Chen, Q.; Sun, Y.; Zhang, W.; Tan, C.P. Molecular Mechanism Underlying Metalloporphyrin- Mediated Fluorescence Sensor for Oxygen Discrimination. J. Nanoelectron. Optoelectron. 2020, 15, 1046-1051. [CrossRef]

29. Salih, E.; Ayesh, A.I. Sensitive $\mathrm{SO}_{2}$ gas sensor utilizing Pt-doped graphene nanoribbon: First principles investigation. Mater. Chem. Phys. 2021, 267, 124695. [CrossRef]

30. Liu, Z.; Chu, Y.; Hou, J.; Fang, Y. Thermochemical Methanation of $\mathrm{CO}_{2}$ by a Gas-Phase Reaction Over Oxygen Deficient $\mathrm{NiCo}_{2} \mathrm{O}_{4}$ Spinel Microspheres. Sci. Adv. Mater. 2020, 12, 1726-1731. [CrossRef]

31. Umar, A.; Ibrahim, A.A.; Ammar, H.; Nakate, U.T.; Albargi, H.B.; Hahn, Y. Urchin like CuO hollow microspheres for selective high response ethanol sensor application: Experimental and theoretical studies. Ceram. Int. 2021, 47, 12084-12095. [CrossRef]

32. Umar, A.; Ibrahim, A.A.; Kumar, R.; Albargi, H.; Alsaiari, M.A.; Ahmed, F. Cubic shaped hematite $\left(\alpha-\mathrm{Fe}_{2} \mathrm{O}_{3}\right)$ micro-structures composed of stacked nanosheets for rapid ethanol sensor application. Sens. Actuators B Chem. 2020, 326, 128851. [CrossRef]

33. Zhu, L.; Zeng, W. Room-temperature gas sensing of ZnO-based gas sensor: A review. Sens. Actuators A Phys. 2017, 267, 242-261. [CrossRef]

34. Mane, A.; Moholkar, A. Orthorhombic $\mathrm{MoO}_{3}$ nanobelts based $\mathrm{NO}_{2}$ gas sensor. Appl. Surf. Sci. 2017, 405, 427-440. [CrossRef]

35. Khudadad, A.I.; Yousif, A.A.; Abed, H.R. Effect of heat treatment on $\mathrm{WO}_{3}$ nanostructures based $\mathrm{NO}_{2}$ gas sensor low-cost device. Mater. Chem. Phys. 2021, 269, 124731. [CrossRef]

36. Schneider, K.; Lubecka, M.; Czapla, A. $\mathrm{V}_{2} \mathrm{O}_{5}$ thin films for gas sensor applications. Sens. Actuators B Chem. 2016, 236, 970-977. [CrossRef]

37. Wei, Q.; Liu, L.; Wu, C. A Novel Net Like Structure Sensor and Gas Detection Performance in Tunnel Construction. J. Nanoelectron. Optoelectron. 2020, 15, 54-58. [CrossRef] 
38. Korotcenkov, G.; Cho, B. Metal oxide composites in conductometric gas sensors: Achievements and challenges. Sens. Actuators B Chem. 2017, 244, 182-210. [CrossRef]

39. Guo, J.; Li, Y.; Jiang, B.; Gao, H.; Wang, T.; Sun, P.; Liu, F.; Yan, X.; Liang, X.; Gao, Y.; et al. Xylene gas sensing properties of hydrothermal synthesized $\mathrm{SnO}_{2}-\mathrm{Co}_{3} \mathrm{O}_{4}$ microstructure. Sens. Actuators B Chem. 2020, 310, 127780. [CrossRef]

40. Hoa, T.T.N.; Hoa, N.D.; Van Duy, N.; Hung, C.M.; Le, D.T.T.; Van Toan, N.; Phuong, N.H.; Van Hieu, N. An effective H 2 S sensor based on $\mathrm{SnO}_{2}$ nanowires decorated with $\mathrm{NiO}$ nanoparticles by electron beam evaporation. RSC Adv. 2019, 9, 13887-13895. [CrossRef]

41. Miller, D.R.; Akbar, S.A.; Morris, P.A. Nanoscale metal oxide-based heterojunctions for gas sensing: A review. Sens. Actuators B Chem. 2014, 204, 250-272. [CrossRef]

42. Vosko, S.H.; Wilk, L.; Nusair, M. Accurate spin-dependent electron liquid correlation energies for local spin density calculations: A critical analysis. Can. J. Phys. 1980, 58, 1200. [CrossRef]

43. Becke, A.D. Density-functional exchange-energy approximation with correct asymptotic behavior. Phys. Rev. A 1988, 38,3098 . [CrossRef] [PubMed]

44. Lee, H.; Lee, Y.; Kang, D.; Yi, Y.; Cho, S.W. In Situ photoelectron spectroscopy and theoretical calculation study of thermally evaporated copper naphthalocyanine. Sci. Adv. Mater. 2020, 12, 1413-1419. [CrossRef]

45. Lee, C.; Yang, W.; Parr, R.G. Development of the Colle-Salvetti correlation-energy formula into a functional of the electron density. Phys. Rev. B 1988, 37, 785. [CrossRef]

46. Miehlich, B.; Savin, A.; Stoll, H.; Preuss, H. Results obtained with the correlation energy density functionals of Becke and Lee, Yang and Parr. Chem. Phys. Lett. 1989, 157, 200. [CrossRef]

47. Frisch, M.J.; Trucks, G.W.; Schelegel, H.B.; Scuseria, G.E.; Robb, M.A.; Cheeseman, J.R.; Scalmani, G.; Barone, V.; Mennucci, B.; Petersson, G.A. Gaussian 09, Revision D.01; Gaussian, Inc.: Wallingford, CT, USA, 2013.

48. Kumar, A.; Thakur, N.; Diwakar; Chandel, T. Tuning of electronic energy levels of NH3 passivated ZnO nanoclusters: A first principle study. Comput. Theor. Chem. 2020, 1176, 112743. [CrossRef]

49. Kaewruksa, B.; Pipornpong, W.; Wanno, B.; Ruangpornvisuti, V. Density functional studies of small gases adsorbed on the ZnO sodalite-like cage and its adsorption abilities. Comput. Theor. Chem. 2013, 1020, 100-107. [CrossRef]

50. Ammar, H.Y.; Badran, H.M.; Umar, A.; Fouad, H.; Alothman, O.Y. ZnO Nanocrystal-Based Chloroform Detection: Density Functional Theory (DFT) Study. Coatings 2019, 9, 769. [CrossRef]

51. Ammar, H.Y. $\mathrm{CH}_{2} \mathrm{O}$ Adsorption on $\mathrm{M}(\mathrm{M}=\mathrm{Li}, \mathrm{Mg}$ and $\mathrm{Al})$ Atom Deposited ZnO Nano-Cage: DFT Study. Key Eng. Mater. 2018, 786, 384-392.

52. Abdel-Latif, I.; Ammar, H. Adsorption and magnetic properties of $\mathrm{Cu}_{11} \mathrm{MO}_{12}(\mathrm{M}=\mathrm{Cu}, \mathrm{Ni}$ and $\mathrm{Co})$ : Ab initio study. Results Phys. 2017, 7, 4419-4426. [CrossRef]

53. O'Boyle, N.M.; Tenderholt, A.L.; Langner, K.M. Software News and Updates cclib: A Library for Package-Independent Computational Chemistry Algorithms. J. Comput. Chem. 2008, 29, 839-845. [CrossRef] [PubMed]

54. Abufager, P.N.; Lustemberg, P.G.; Crespos, C.; Busnengo, H.F. DFT Study of Dissociative Adsorption of Hydrogen Sulfide on $\mathrm{Cu}(111)$ and $\mathrm{Au}(111)$. Langmuir 2008, 24, 14022-14026. [CrossRef] [PubMed]

55. Segall, M.D.; Shah, R.; Pickard, C.J.; Payne, M.C. Population analysis of plane-wave electronic structure calculations of bulk materials. Phys. Rev. B 1996, 54, 16317-16320. [CrossRef]

56. Kasap, S.O. Principles of Electronic Materials and Devices; McGraw-Hill: Boston, MA, USA, 2006; pp. $378-405$.

57. Ammar, H.; Badran, H. Effect of CO adsorption on properties of transition metal doped porphyrin: A DFT and TD-DFT study. Heliyon 2019, 5, e02545. [CrossRef]

58. Ravan, B.A.; Jafari, H. DFT study on electronic and optical properties of halogen-adsorbed hexagonal boron nitride. Comput. Condens. Matter 2019, 21, e00416. [CrossRef]

59. Demir, S.; Fellah, M.F. A DFT study on Pt doped (4,0) SWCNT: CO adsorption and sensing. Appl. Surf. Sci. 2019, 504, 144141. [CrossRef]

60. Zhang, T.-T.; Tang, Q.-L.; Yao, M.-Y.; Chen, C.; Duan, X.-X.; Wang, Q.; Zhang, X.; Zhang, M.-L.; Hu, W. Quantum chemical DFT study of molecular adsorption of $\mathrm{H}_{2} \mathrm{~S}$ on clean and chemically modified $\mathrm{Au}(110)$ surfaces. Appl. Surf. Sci. 2020, $542,148595$. [CrossRef]

61. Wang, Y.; Lin, Q.; Wang, C.; Li, K.; Sun, X.; Song, X.; Gao, Y.; Ning, P. Influence of drying and calcination temperatures for Ce-Cu-Al trimetallic composite catalyst on simultaneous removal $\mathrm{H}_{2} \mathrm{~S}$ and $\mathrm{PH}_{3}$ : Experimental and DFT studies. J. Environ. Sci. 2020, 104, 277-287. [CrossRef]

62. Yoosefian, M.; Zahedi, M.; Mola, A.; Naserian, S. A DFT comparative study of single and double $\mathrm{SO}_{2}$ adsorption on Pt-doped and Au-doped single-walled carbon nanotube. Appl. Surf. Sci. 2015, 349, 864-869. [CrossRef]

63. Rad, A.S.; Ayub, K. $\mathrm{O}_{3}$ and $\mathrm{SO}_{2}$ sensing concept on extended surface of $\mathrm{B}_{12} \mathrm{~N}_{12}$ nanocages modified by Nickel decoration: A comprehensive DFT study. Solid State Sci. 2017, 69, 22-30. [CrossRef]

64. Eid, K.; Ammar, H. Adsorption of $\mathrm{SO}_{2}$ on Li atoms deposited on $\mathrm{MgO}$ (100) surface: DFT calculations. Appl. Surf. Sci. 2011, 257, 6049-6058. [CrossRef]

65. Soliman, I.; El-Nahass, M.; Eid, K.; Ammar, H. Vibrational spectroscopic analysis of aluminum phthalocyanine chloride. experimental and DFT study. Phys. B Condens. Matter 2016, 491, 98-103. [CrossRef] 
66. Shalabi, A.; Aal, S.A.; Kamel, M.; Taha, H.; Ammar, H.; Halim, W.A. The role of oxidation states in $\mathrm{FA}_{1} \mathrm{Tl}^{\mathrm{n}+}(\mathrm{n}=1,3)$ lasers and $\mathrm{CO}$ interactions at the (100) surface of NaCl: An ab initio study. Chem. Phys. 2006, 328, 8-16. [CrossRef]

67. Shalabi, A.; Aal, S.A.; Halim, W.A.; Ammar, H. Artificial polarization effects on $\mathrm{FA}_{1}: \mathrm{Sr}^{2+}$ lasers and $\mathrm{NO}$ interactions at $\mathrm{NaCl}(001)$ surface: First principles calculations. J. Mol. Struct. THEOCHEM 2007, 823, 47-58. [CrossRef]

68. Kittel, C. Introduction to Solid State Physics; John Wiley and Sons: Hoboken, NJ, USA, 2005; pp. $216-226$.

69. Guo, J.; Guan, L.; Wang, S.; Zhao, Q.; Wang, Y.; Liu, B. Study of hydrogen adsorption on the Ti $(0001)-(1 \times 1)$ surface by density functional theory. Appl. Surf. Sci. 2008, 255, 3164-3169. [CrossRef] 